\title{
The Desert Spontaneous Plants Used in Saharan Phytotherapy: Case of Tidikelt Region
}

\author{
Aicha Blama Merzaia \\ Agri-food Technologies Division, National Institute for Agronomic Research of Algeria (INRAA), Algiers 16200, Algeria
}

\begin{abstract}
The local plant resources adapted to the desert harsh geomorphologicl environment are a landmark that characterizes the Saharan region: erg, dunes, and wadis. This work emphasizes on some results obtained through a study conducted in 2011, based on surveys and field observations in the Tidikelt oases (in Salah, wilaya of Tamenrasset) which is implanted in the south of Algeria. The objective was the study of traditional herbal medicine using the spontaneous medicinal herbs, which constitute one of the socio-cultural aspects of Saharan society in Algeria. Traditional medicine is one reflect of the knowledge and how to live of the local population. Desert people know the various herbs 'Achebe', and its nomenclature. They indicated their site or places of local presence, as well as its own peculiarities and their uses. Our goal is to contribute in enhancing the interest of valorization of these plants in the therapeutic and eventually industrial uses. For that, we need to integrate this perspective into local economic development policies valuing the diversity of plant resources from Tidikelt in the Algerian Sahara.
\end{abstract}

Key words: Spontaneous medicinal herbs, Tidikelt, traditional herbal medicine, Sahara.

\section{Introduction}

Algeria is known by its diversity in medicinal plants, as well as their various popular uses in all of the regions of the country. The new flora of the Algeria and southern desert regions mentioned 289 scarce species, 647 very rare, 35 extremely rare and 168 endemic [1].

The abundance of medicinal plants in the Algerian flora is undeniable. Their use in traditional medicine is seeking wide interest in recent scientific studies [2]. In this context, we seek the valorization of the local knowledge related to the traditional use of medicinal herbs.

\section{Material and Methods}

Ethnobotanical investigations were conducted on a sample of 100 adult people. The choice of this target category is justified by the experience of people supposedly more interesting for our study, in particular, herbalists nomads or pastors of these

\footnotetext{
*Correspondent author: Aicha Blama Merzaia, Sociologists, rearcherch fields: ethnobotanical study, agri-food and development. E-mail: blama.aicha@gmail.com.
}

regions that know well enough plants that will feed which their cattle, and use for designating a fairly consistent nomenclature [3].

The investigation focused on the medicinal plants spaces in the region, their growth area and their use by local population in the traditional therapy.

The survey was enriched by participatory observations with nomads, healers and herbalists.

\section{Presentation of the Study Area}

Tidikelt is located in the central of Sahara desert of Algeria.

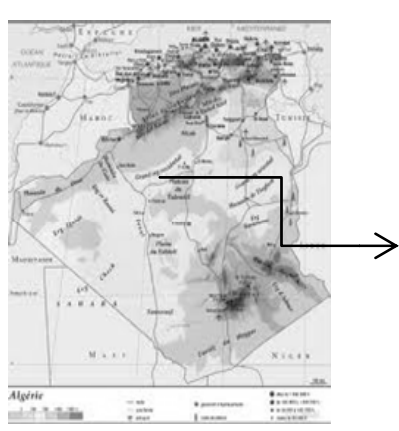

(a)

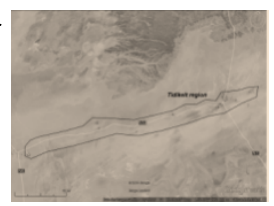

(b)
Fig. 1 (a) Location of the study area (Larousse: Algeria, geography physique), (b) GIS cell of INRAA. Source: Google Earth. 
The region [4] is a set on older geological structure: the plateau of the Tadmait is a vast mountainous area (average of 600 meter altitude) [5], defines Tadmait, a flat and continuous space, as a real hamada.

The region is characterized by the presence of the tablecloth of continental insert, which possesses possessing natural outlet (the foggaras). It is a region where the main wadi collects from the lowest point in Tidikelt.

The climate is desert continental type, it is very arid, hot and dry and characterized by

- Low precipitation $(<20 \mathrm{~mm} / \mathrm{yr})$.

- A long insolation (3,800 h/year).

- Intense evaporation (FTE > 2,000 mm/year).

- High temperatures and large thermal amplitudes.

- Frequent wind (more than $60 \%$ of the winds have a speed greater than $5 \mathrm{~m} / \mathrm{s}$ during the year).

The soils are alkaline and are poor in organic matter.

The total population of the area of Tidikelt is 51,041 inhabitants of which 14,217 are rural. The population is a structure of several ethnic groups. Its geographical location in the center of the Sahara gave it a key importance; Tidikelt became a Saharan capital where trade is very active. This social mix allows sharing, exchanging and transmitting local knowledge and way of living of different culture including phototherapy and the traditional use of medicinal herbs.

\section{Results and Discussion}

Despite the scarcity of plants and the weakness of the canopy in the desert, Tidikelt contains occasional annual plants mainly in the wadi. Perennial vegetation is exclusively phreatophyte type. Spontaneous medicinal herbs are generally found in the wadi or on the regnorth and west of Tidikelt. Indigenous population, given its local socio-cultural attachment and its knowledge of environment, uses plants known as medicinal in traditional medicine. Indeed, the local population, sedentary as well as nomads, detains a valuable and highly developed knowledge on the therapy of plants growing in their territory. Local people hold the expertise in harvesting, conservation and use of spontaneous medicinal herbs and crops in therapy.

Our investigation has shown that women and men have a high knowledge on medicinal plants and their usage (Table 1).

The results corroborate the local population commitment to the valorization of plant resources in this area despite their scarcity. According to the investigation results, women seem more attached to the use of plants compared to men, but men possess undeniable knowledge on location of the spontaneous medicinal herbs available in their area (the Sahara man is an innate guide). Users of these territories contribute to the valorization and the preservation of this natural and cultural heritage.

The warm days and cools nights encourage the occurrence of frequent and widespread diseases in the Saharan region. Medicinal plant species are commonly to cure most of these diseases: headaches or migraines, rheumatism, blood pressure and diseases of respiratory system such as coughs and cold, etc..

Other diseases related to gastrointestinal system, such as gastric ulcers, intestinal worms, constipation are also treated with medicinal herbs in the traditional medicine.

The richness of these spaces in spontaneous medicinal plants led to their utilization in alternative therapies in the region. The following Table 2 shows inventory of medicinal plants, localization and alternative therapy use:

Table 1 Use of spontaneous plants by the people of Tidikelt.

\begin{tabular}{lllll}
\hline \multirow{2}{*}{ Gender } & \multicolumn{3}{c}{ Yes } & No \\
\cline { 2 - 5 } & Number & $\%$ & Number & $\%$ \\
\hline Male & 44 & 88 & 6 & 12 \\
Female & 47 & 94 & 3 & 6 \\
Total & 91 & 91 & 9 & 9 \\
\hline
\end{tabular}


Table 2 Inventory of the spontaneous medicinal plants and their therapeutic use in the region of Tidikelt.

\begin{tabular}{|c|c|c|c|c|c|}
\hline Vernacular name & Scientific name & Family & Utilization & Location & Recipes \\
\hline Oum draiga/akaman & $\begin{array}{l}\text { Ammondcus } \\
\text { leautrecus }\end{array}$ & Asteraceae & Medicinal & Dune/wadi & $\begin{array}{l}\text { Aromatic, } \\
\text { antispasmodic, } \\
\text { carminative }\end{array}$ \\
\hline Agaia & Zygophyllum album & Zygophylacees & Medicinal & Wadi & Diabetes \\
\hline Aguergur & Cassia obovata & Caesalpiniaceae & Medicinal & Wadi & Purgative, laxative \\
\hline Chendgoura/tagmzaout & Aerva javanica & Pedaliaceae & & Plateau & Fever, stomach pain \\
\hline Chih/thrgli & Artimisia herba-alba & Compositae & Medicinal & Wadi & Intestinal worms, colic \\
\hline Izkher/lemad/tibermet & $\begin{array}{l}\text { Cymbopogon } \\
\text { schoenanthus }\end{array}$ & Poaceae & Medicinal & Wadi/plateau & $\begin{array}{l}\text { Rubéfiante, digestive, } \\
\text { asthma }\end{array}$ \\
\hline Garetofa/taquet & Cotula cinerae & Asteraceae & $\begin{array}{l}\text { Forage/ } \\
\text { medicinal }\end{array}$ & Wadi/plateau & $\begin{array}{l}\text { Fever especially in } \\
\text { childhood as a poultice. }\end{array}$ \\
\hline Gaetofa ozouaza & Cotula anthemoides & Asteraceae & Medicinal & Wadi/plateau & $\begin{array}{l}\text { Treating scorpion } \\
\text { stings and snake bites }\end{array}$ \\
\hline Gouzah & $\begin{array}{l}\text { Deverra chlorantha } \\
\text { /pituranthos } \\
\text { chloranthus }\end{array}$ & Apiaceae & $\begin{array}{l}\text { Forage/ } \\
\text { medicinal }\end{array}$ & Wadi plateau & Colic, kidney diseases \\
\hline Guetaf. & Atriplex halimus & $\begin{array}{l}\text { Chenopodiaceae/ } \\
\text { pedaliaceae }\end{array}$ & $\begin{array}{l}\text { Forage/ } \\
\text { medicinal }\end{array}$ & Wadi/plateau & Regulator of hormones \\
\hline Sedretedoua & $\begin{array}{l}\text { Haplophylum } \\
\text { tuberculatum }\end{array}$ & Rutaceae & Medicinal & Wadi/plateau & $\begin{array}{l}\text { Emmenagogue, } \\
\text { stomach ache, bloating }\end{array}$ \\
\hline Nougd/akerked & Asteriscus pygmeus & Compositae & & Wadi/plateau & \\
\hline Mokhinza & Cleome arabica & Capparidaceae & Medicinal & Wadi/plateau & $\begin{array}{l}\text { Heal wounds, } \\
\text { rheumatism relief }\end{array}$ \\
\hline
\end{tabular}

\section{Conclusions}

The uses of medicinal plants are one of the socio-cultural aspects of the Saharan society in Algeria. Indigenous people possess incontestable knowledge on growing and use of these species allowing them to preserve this socio-cultural heritage inspired by nature. Obviously, women, compared to men, are significantly attached to the culture of these natural resources use, underlining the relationship between women and the land, basis of reproduction and growth, and symbol of generosity and purity.

Moreover, our study also shows the interest of valorization and preservation of knowledge related to the use of medicinal plants that grow in a spontaneous manner in more or less specific territories. We highlight the need to strengthen the valorization of these natural resources in local development policies starting with the enhancement of the already existing expertise and local knowledge, especially that Algeria has shown a special interest in these resources through the establishment of nature reserve and 10 national parks.

\section{References}

[1] Azzi, L. 1999. "The biodiversity in Algeria, lives and nature." The magazine of the national Agency for the Nature Conservation, 7.

[2] Basil, A., Chibane, M., Madani, K., and Oukil, N. 2012. "Antibacterial Activity of Polyphenols Extracted from a Medicinal Plant Flora of Algeria.” Origanum glandulosum Desf. Phototherapy 10 (1): 2-9.

[3] Mm, J. A., and Battandier, L. T. 1911. Contribution to the Flora of the Country of the Tuareg. the Bulletin of the Botanical Society of France, 623-629.

[4] The Atlas of the Environment of Algeria, 2002, Ed. Symbiose-communication-environment. Alegria, 16.

[5] The National Office of Studies for the Rural Development (BNEDER), 1998. Study of Director General Plan for Development of the Saharan Regions, tom1, 6. 